\title{
Analytical Approach to the Literature of Cupping Therapy
}

\author{
Serhat Koran, $\mathrm{MD}^{\dagger} \cdot$ Arzu Irban, $\mathrm{MD}^{1}$ \\ Department of Family Medicine, Istanbul Medipol University, \\ ${ }^{1}$ Department of Anesthesiology, Istanbul Health Sciences University
}

Received: April 7, 2021 / Revised: June 2, 2021 / Accepted: June 28, 2021

(C) 2021 J Korean Soc Phys Med

\section{| Abstract}

PURPOSE: This study aims to reveal the prevalence, therapeutic efficacy and undesirable side effects of cupping therapy all over the world from past to present.

METHODS: This meta-analysis is based on the data obtained by scanning the keyword "cupping therapy" from the Pub-Med system, which is an international database. The date range has been set as 1950-2019. Local databases were not included. Cupping therapy studies combined with other complementary therapies such as acupuncture, moxa and hirudotherapy are also included in the meta-analysis.

RESULTS: A total of 381 scientific studies were found on cupping therapy. Of these studies 127 wererandomized controlled trials (RCSs). Cupping treatment has been found effective in studies of painful conditions such as herpes zoster pain, fibromyalgia, back pain, neck pain, headache and acute injury pain. In addition, the effectiveness of cupping therapy was found to be high in studies related to bone / muscular system diseases such as osteoarthritis, rheumatoid arthritis, ankylosing spondylitis, gout, carpal tunnel syndrome,

$\dagger$ Corresponding Author: Serhat Koran

drserhat28@yahoo.com, https://orcid.org/0000-0003-2641-3965

This is an Open Access article distributed under the terms of the Creative Commons Attribution Non-Commercial License (http://creativecommons.org/licenses/by-nc/3.0) which permits unrestricted non-commercial use, distribution, and reproduction in any medium, provided the original work is properly cited. cervical spondylosis. In addition, cupping treatment is also promising in studies on skin diseases, neurological diseases, respiratory system diseases and cardiovascular system diseases.

CONCLUSION: Recently, there has been an increase in the number of RCSs related to cupping therapy. The vast majority of this increase has been made in European and American countries rather than in Far Eastern countries. Studies on cupping therapy, which have been and will be carried out in the future, will provide evidence-based indication of whether cupping therapy is effective. and it will allow more patients to benefit from this treatment, which has a very low rate of side effects and complications.

Key Words: Cupping therapy, Complementary therapies, Hirudotherapy

\section{Introduction}

Cupping therapy is the traditional treatment method applied in the far east for thousands of years. Cupping therapy is applied to the skin by vacuuming through various equipments [1,2]. While vacuuming was used with cups made of bamboo, metal and soil in ancient times, today it is applied with specially produced sterile glass and plastic cup [3]

According to the cupping therapy application method, it is divided into two as dry cupping and wet cupping 
(blood letting) [1,2]. Dry cupping is the process of applying vacuum by creating negative pressure with mug to certain areas on the skin $[1,3,4]$. In dry cupping, there is no incision or liquid draw on the skin. The goal of dry cupping therapy is to increase the blood flow by creating a massage effect in the applied area, to create a pain relieving effect and to operate the lymphatic system $[2,4]$.

It has been observed that the efficacy of the treatment is increased in combination with far east treatment methods such as acupuncture and moxa applied locally after dry cupping therapy $[2,3]$. Dry cupping therapy can also be applied in patients where wet cupping cannot be applied or in patients who do not want to make an incision on their skin [4].

Wet cupping therapy is commonly referred to as "blood letting", a word of Arabic origin [1,2]. Blood letting is the process of creating scratches in certain parts of the body and vacuuming fluid in these areas (Fig. 4) [3,4]

The main purpose in blood letting is not the process of taking blood from the body as it is thought. It is aimed to remove the chemicals and toxins that accumulate in the intercellular space under the incision, which can cause diseases [4]. There is no blood in the vein taken from the skin in the treatment of blood letting; intercellular fluid called "interstitial fluid" under the skin. In the researches made it was shown that heavy metals such as aluminum, lead, mercury, silver in the liquid vacuumed with blood letting are higher than the amount in the blood taken from the vein; these heavy metals were shown to be removed from the body during the blood letting process [4].

The blood letting treatment is applied to the back, head, shoulders, waist, chest, legs and other body parts depending on the complaint [4]. Blood letting process takes about half an hour. It is recommended to have at least 3-4 hours of fasting before the procedure, and it is recommended not to consume food of animal origin such as meat, milk, yoghurt, eggs, butter for approximately 72 hours before the procedure, the day of the procedure and the day after the procedure [4].

After the area where blood letting is to be applied is disinfected, firstly negative pressure is applied to the area with the help of a cup and the blood flow of the area is ensured to increase. Later, the cups are removed and small scratches are applied with the help of sterile scalpel, so that their length does not exceed $1 \mathrm{~cm}$ and the depth does not exceed 1-2 $\mathrm{mm}$. Then vacuum is applied to this area again. It is waited until liquid stops coming and the liquid in it freezes. Then the mugs are opened, the incoming liquids are collected. After cleaning, it is closed with dressing. It is recommended not to take a shower at least 12 hours after the procedure [4].

Traditional and complementary medicine applications applied in Far Eastern medicine are generally applied together and the points where vacuum is applied in cupping therapy are acupuncture points [1].

Although blood letting treatment seems to be an easy practical procedure, it is a medical intervention that should be applied by physicians. If not careful, there is a risk of undesirable effects such as skin burns, skin abscesses and skin infections. In addition, cup treatment is not a treatment method that can be applied in every patient. It should not be used in patients with deep vein thrombosis, hypotension, varicose veins, cancer, severe anemia, heart failure or kidney failure. Bloodletting treatment should also be avoided in women who are in menstrual periods or pregnancy. Again, patients who use blood thinning medication should be very careful in their blood letting applications.

This study is a meta-analysis prepared to investigate the prevalence, therapeutic efficacy and undesired side effects of cupping therapy from past to present all over the world.

\section{Method}

Using 'cupping therapy' as a keyword; the data were 
taken from the international database Pub-Med system in this meta-analysis searching for the therapeutic effect of cupping therapy, regional databases were not included in the study. In the Pub-Med database filters section; classical article, clinical study, meta-analysis, review and case studies were selected. The year range was determined as 1950-2019. Cupping therapy studies combined with other complementary therapies such as acupuncture, moxa and hidrotherapy were also included.

\section{Findings}

As a result of filtering, 381 scientific studies on cupping therapy were reached. Among these, 127 RCSs (33\%), 3 meta-analyzes (1\%), 135 non-randomized trials $(35 \%), 30$ reviews (8\%), 15 questionnaire studies (4\%), 64 case reports (17\%) and 7 other studies (2\%) were made on subjects.

RCS contains herpes zoster pain, active herpes simplex infection, fibromyalgia, low back pain, headache, neck pain, injury, constipation, osteoarthritis, rheumatoid arthritis, allergic rhinitis, chronic urticaria, acne vulgaris, facial paralysis, chronic fatigue syndrome, ankylosing spondylitis, gout arthritis, carpal tunnel syndrome, acute eczema, asthma, hiccups, metabolic syndrome, hypertension, hyperlipidemia, obesity, heart rhythm, insomnia, effect on quality of life in chronic patients, depression in diabetes, neurodermatitis, chloasma, postoperative nausea, cervical spondylosis, peroneal nerve palsy, cerebral palsy, its effect on iron overload therapy, brachial paresthesia, upper extremity spasticity, its effect on the immune system, its effect on oxidative stress and forensic medicine.

The efficacy of cupping therapy was high in all 22 RCSs performed in cases of pain such as Herpes zoster pain, fibromyalgia, low back pain4, neck pain3, migraine pain2, tension-type headache, acute injury pains. In the reviews on fibromyalgia, low back pain and headache, it was concluded that cupping therapy is effective in the treatment of pain, but more studies are needed [5-10].
In addition, in 4 studies in which its effects on osteoarthritis were investigated (4 pieces), in 34 RCSs performed on diseases such as rheumatoid arthritis (1 piece), ankylosing spondylitis (2 pieces), gout, carpal tunnel syndrome (2 pieces), cervical spondylosis and limb spasticity, cupping therapy was found to be effective in bone / musculature diseases. In the reviews on osteoarthritis, carpal tunnel syndrome, ankylosing spondylitis, it has been concluded that cupping therapy is effective in musculature diseases [11-14].

In 16 RCS studies on neurodermatitis, herpes simplex, chronic urticaria, acne vulgaris, and acute eczema, results were obtained regarding the effectiveness of wet cupping therapy. In a review on skin diseases, it was concluded that "Although there is not enough study, cupping therapy is promising in skin diseases" $[15,16]$. When we look at the effectiveness of cupping therapy in nervous system diseases; there are results showing that it is effective in 15 RCSs performed in diseases such as facial paralysis, peroneal nerve palsy, cerebral palsy, brachial paresthesia, postherpetic neuralgia, migraine and trigeminal neuralgia [8,17-20].

Apart from this, results were obtained showing that it is beneficial in RCS performed on subjects such as heart rhythm, asthma, postoperative nausea, depression and chronic fatigue syndrome [9,1-24].

In a study on the effect of cupping therapy on metabolic syndrome, serum "high-sensitivity C-reactive protein" and "heat shock protein 27 " levels were examined and there was no significant difference between before and after cupping therapy [25]. In another study on metabolic syndrome, it was concluded that cupping therapy was not effective on lipid profile[26]. However, in another study conducted on healthy but hyperlipidemic male patients who did not receive antihyperlipidemic treatment, it was concluded that cupping therapy decreased the LDL / HDL ratio [27].

In a randomized controlled study on the effect of cupping 
therapy on hypertension, a significant decrease in systolic blood pressure was observed in the group having cupping therapy and 4 weeks after the procedure, but in the 8-week follow-up, the blood pressure was observed to increase again in the blood letting group. Local studies were also included in a review evaluating the effect of cupping therapy on hypertension. Studies involving cupping therapy and comparisons with acupuncture concluded that cupping therapy was effective in hypertension [28]. In another review performed on hypertension, there is not enough evidence that cupping therapy can be effective in hypertension, but further studies are needed .

It was concluded in a review on cardiovascular health that there was not sufficient data and further studies were required [29].

In a study on the effect of cupping therapy on weight loss, it was concluded that cupping therapy + acupuncture therapy was more effective than acupuncture therapy itself [30].

In the study on the effect of cupping therapy on autoimmune diseases, autoantibody, inflammatory mediators and serum ferritin levels were examined and it was concluded that cupping therapy was promising in autoimmune diseases [31].

A study on the effectiveness of cupping therapy in thalassemia and iron overload conditions concluded that wet cupping therapy was effective [32] .

In the study on the effects of cupping therapy on infertility, it was concluded that cupping therapy may be effective in infertility, but further studies are required [33].

There are studies investigating the effect of cupping therapy on heavy metal detoxification, which concluded that it was effective in removing heavy metals such as aluminum, lead, mercury and silver from the body $[4,34]$.

Apart from these, there are case reports that cupping therapy is effective in the treatment of superficial thrombophlebitis, its therapeutic effect in mastitis, insect sting with lymphangitis, epicondylitis treatment, gluteal nerve junction syndrome and epistaxis treatment [35-38].
Survey studies on cupping treatment are about evaluating the knowledge and interests of the public and physicians on alternative medicine and cupping treatment. These studies were performed in Korea, China, Norway, England, Vietnam, Saudi Arabia, Thailand and Iran [39-44].

Three meta-analyzes were accessed in cupping treatment. In these meta-analyzes, local databases were used apart from the international database. In these meta-analyzes, it was concluded that "The quality and quantity of RCS in cupping treatment appears to have increased over the past 50 years, and the majority of studies show potential benefits over pain conditions, herpes zoster and other diseases" [45].

In addition, there are studies performed on the use of placebo silicon in cupping treatment, the effect of differences in anatomical back structure instead of mug, awareness of cup trace in forensic autopsies and cupping therapy device innovations $[46,47]$.

20 of the case reports are related to the effectiveness of cupping therapy, and 44 case reports are on the side effects of cupping therapy. Most of the case reports on side effects were made in the last 10 years. Case reports related to their negative effects were mostly on side effects on the skin. There are case reports related to burns, bullae, keloid, hyperpigmentation reaction, infection, skin scar, skin abscess, epidural abscesses. There are also cases of koebner phenomenon in psoriasis. One case was related to lipoma formation after dry cupping. Cardiac hypertrophy due to anemia was reported after a prolonged cupping. In one case, extracranial vertebral artery rupture was reported after hematoma occurring in the nape after cupping therapy. It was stated that all these side effects were mostly occurred after wet cupping therapy performed by non-competent people $[48,49]$.

The distribution of all these studies by years and regions can be seen in Fig. 1, 2. Although all studies have increased in recent years, there has been an increase especially in RCSs in recent years (Fig. 1, 3). 


\section{Discussion}

Many theories have been proposed regarding the possible mechanisms of action of cupping therapy. These effects can be classified as local effects, gate control theory, effects on the neural system, effects on the hematological system, effects on the immune system, reflex mechanisms, and placebo effect [4].

Kutivisceral reflex theory is one of the neuronal mechanisms of action. According to this theory, there are relations with internal organs in the relevant skin areas along the segments that the spinal nerves innervate. These relationships are defined as a kutivisceral / viserokuteneal reflex. In a pathological condition to occur in the organ, the signal to the relevant skin area may cause skin changes or pain in this area. According to this theory, starting from this mechanism, it is possible to contribute to the treatment of the organ with cupping therapy to be made to the segment related to the diseased organ.

Another important mechanism is the gate control theory. According to the gate control theory, it stimulates the thick unmyelinated A delta fibers with incision and vacuum created in wet cupping application, and closes the entrance doors of pain signals reaching the spinal core with the group $\mathrm{C}$ thinner myelinated nerve fibers in the substantia gelatinosa. In addition, by stimulating the mechanoreceptors, other pain stimulation is prevented over nociceptive afferent fibers and the stimulation is prevented from moving upward [7].

In Chinese medicine, there are 5 basic items and they have characteristic features. There are energy channels of organs in the body. According to this theory, disruptions in the flow of these channels cause diseases in the organ that channel acts on. Energy and blood blockages that may occur in these channels can be opened with wet cupping application.

Another mechanism is to ensure the excretion of toxins and heavy metals accumulated under the skin with the application of blood letting and to prevent these substances from accumulating in cells such as muscle and nerve cells and causing diseases [4].

Although not all of these mechanisms are clear, when we look at RCS showing that cup therapy can be effective, the main mechanism of treatment, regardless of the source of effect, is the effect on inflammation, oxidation and chemical toxicity [50]. When we look at the pathogenicity of the pain, the main reason is increased pressure in the interstitial area and increased neurotransmitters (substance-P, calcitonin receptor gene associated peptide and other neurotransmitter in afferent nerves). Especially the increase of Substance-P increases the release of inflammatory mediators such as histamine, tumor necrosis factor-alpha and leukotriene [10]. The nerve endings (nociceptors) become more sensitive during inflammation and this causes a sensation of pain in the pathological region [10]. When the first vacuum pressure is applied during blood letting treatment, interstitial fluids, neurotransmitters and other mediators in the region are collected under the cup thanks to the negative suction pressure since there is no incision. Later, this area is cut and vacuumed again so that it causes the inflammatory mediators collected here to be absorbed into the cup [10].

Most of the studies carried out in Far East Countries and the number of the studies carried out in Europe and America have increased in the last 10 years (Fig. 1, 2). Especially, the increase in the number of RCSs will cause the interest in cupping therapy to increase (Fig. 3).

Recent studies have mostly been combined with other traditional therapies such as acupuncture and moxa. In all these studies, it was concluded that treatments such as acupuncture and moxa were more effective than their effectiveness alone [2].

RCS contains pain due to herpes zoster infection, active herpes simplex infection, fibromyalgia, low back pain, mig raine and tension-type headache, neck pain, injury, constipation, osteoarthritis, rheumatoid arthritis, allergic rhinitis, chronic urticaria, acne vulgaris, facial paralysis, 


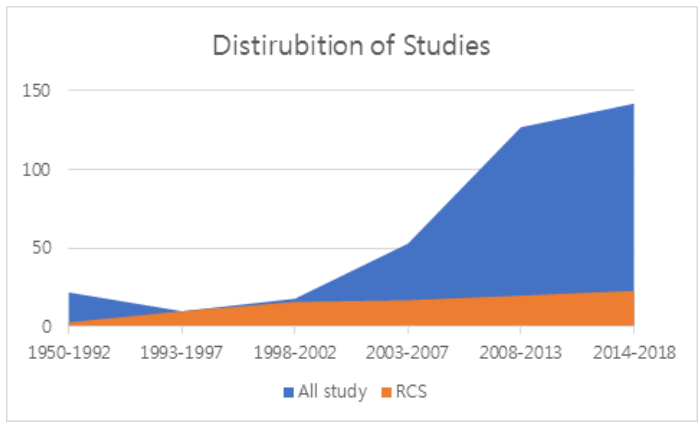

Fig. 1. Distribution of studies by years.

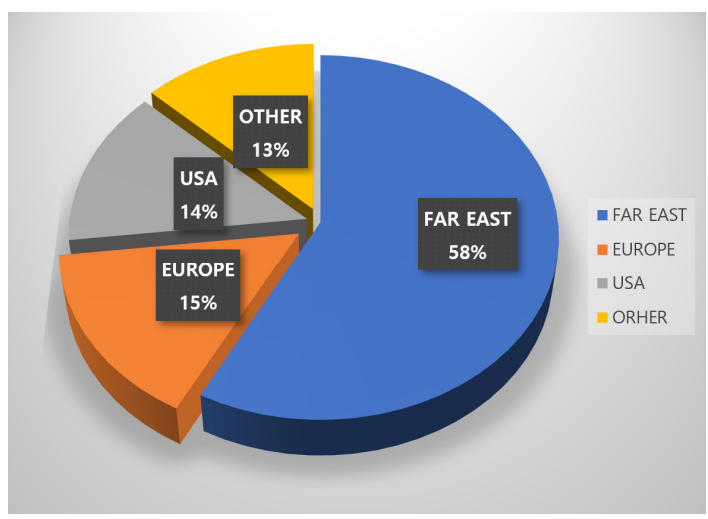

Fig. 2. Regional distribution of all studies.

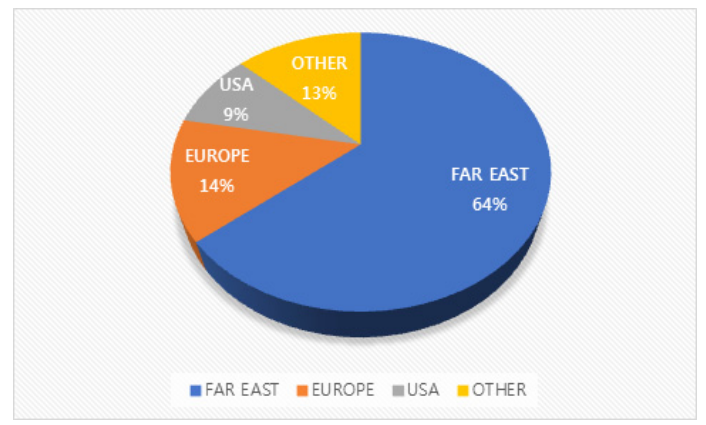

Fig. 3. Regional distribution of RCSs.

chronic fatigue syndrome, ankylosing spondylitis, gout arthritis, carpal tunnel syndrome, acute eczema, asthma, hiccups, metabolic syndrome, hypertension, hyperlipidemia, obesity, heart rhythm, insomnia, effect on quality of life in chronic patients, depression in diabetes, neurodermatitis, chloasma, postoperative nausea, cervical spondylosis,

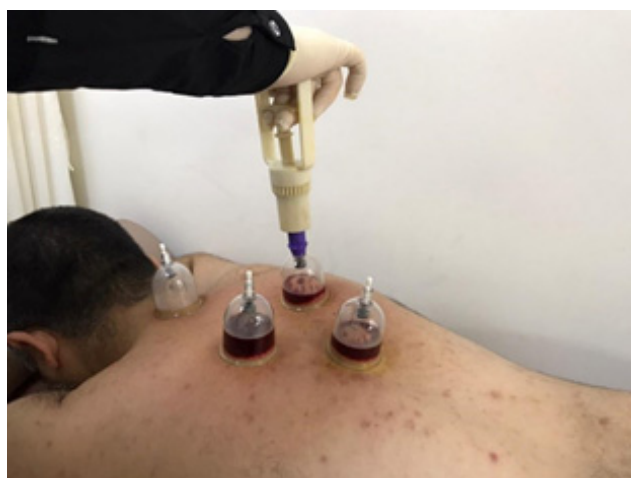

Fig. 4: Cupping therapy application today.

peroneal nerve palsy, cerebral palsy, its effect on iron overload therapy, brachial paresthesia, upper extremity spasticity, its effect on the immune system, its effect on oxidative stress and forensic medicine. In these studies, blood letting treatment was applied and any significant side effects were not observed in these studies. There is no placebo control group in all studies, since placebo cannot be administered in cupping therapy by nature. One study was about the use of a silicone cup for placebo purposes. In this study, it was concluded that "Although the placebo cup is effective, further study is required." (Table 1) [46].

The majority of RCSs performed on cupping treatment are on pain, musculoskeletal, skin diseases, and nervous system diseases. The majority of reviews have been also made on these issues (Table 1).

Wet cupping was applied in all RCSs performed on pain. In these studies, it has been concluded that cupping therapy is effective. In the reviews on this subject, it was concluded that cupping therapy was effective in the treatment of pain (Table 1) $[5,8,9]$. It was concluded in one each RCS carried out lower back and neck pain that dry cupping therapies were also effective on pain. Cupping therapy points were determined according to the localization of patients' pain, and no standard treatment protocol was applied (Table 1) [9].

In studies on muscle-bone diseases, wet cupping therapy was also applied. In addition, in 34 RCSs performed on 
Table 1. Studies on Cupping Therapy

\begin{tabular}{|c|c|c|c|c|c|}
\hline Name of the study & Type of scientific study & $\begin{array}{l}\text { Author of } \\
\text { study/year }\end{array}$ & Subject of study & Result & $\mathrm{p}$ value \\
\hline $\begin{array}{l}\text { Progress of researches on the } \\
\text { mechanism of cupping therapy }\end{array}$ & Review & $\begin{array}{l}\text { Cui S/ } \\
2012\end{array}$ & $\begin{array}{l}\text { Cupping therapy } \\
\text { mechanism of } \\
\text { action }\end{array}$ & & \\
\hline Cupping Therapy. & Review & $\begin{array}{l}\text { Furhad S/ } \\
\qquad 2020\end{array}$ & $\begin{array}{l}\text { Cupping therapy } \\
\text { mechanism of } \\
\text { action }\end{array}$ & & \\
\hline $\begin{array}{l}\text { Cupping therapy: A prudent remedy } \\
\text { for a plethora of medical ailments. }\end{array}$ & Review & $\begin{array}{l}\text { Mehta P/ } \\
2015\end{array}$ & $\begin{array}{l}\text { Cupping therapy } \\
\text { application } \\
\text { techniques }\end{array}$ & & \\
\hline $\begin{array}{l}\text { The medical perspective of cupping } \\
\text { therapy: Effects and mechanisms of } \\
\text { action. }\end{array}$ & Review & $\begin{array}{l}\text { Al-Bedah } \\
\text { AM/2019 }\end{array}$ & $\begin{array}{l}\text { Effects of cupping } \\
\text { therapy, } \\
\text { Mechanism of } \\
\text { action of cupping } \\
\text { therapy }\end{array}$ & & \\
\hline $\begin{array}{l}\text { Effects of moving cupping therapy on } \\
\text { hip and knee range of movement and } \\
\text { knee flexion power: a preliminary } \\
\text { investigation. }\end{array}$ & $\begin{array}{l}\text { Pre- and } \\
\text { post-procedure } \\
\text { evaluation in } 21 \\
\text { healthy individuals. }\end{array}$ & $\begin{array}{l}\text { Murray D/ } \\
2019\end{array}$ & $\begin{array}{l}\text { Effect of dry } \\
\text { cupping therapy on } \\
\text { hip and knee joint } \\
\text { function }\end{array}$ & $\begin{array}{l}\text { Cupping therapy showed a significant increase } \\
\text { in hip and knee range of motion measurements } \\
\text { by } 7 \% \text { in straight leg raise and } 4 \% \text { in popliteal } \\
\text { angle test. }\end{array}$ & $\mathrm{p}<.005$ \\
\hline $\begin{array}{l}\text { Wet cupping therapy for treatment of } \\
\text { herpes zoster: a systematic review of } \\
\text { randomized controlled trials. }\end{array}$ & $\begin{array}{l}\text { Eight randomized } \\
\text { controlled trials included } \\
\text { (651 patients total) }\end{array}$ & $\begin{array}{c}\text { Cao H./ } \\
2010\end{array}$ & Herpes zoster & $\begin{array}{l}\text { Wet cupping appears to be effective in the } \\
\text { treatment of herpes zoster. }\end{array}$ & \\
\hline $\begin{array}{l}\text { Traditional Chinese Medicine for } \\
\text { treatment of fibromyalgia: a systematic } \\
\text { review of randomized controlled trials. }\end{array}$ & $\begin{array}{l}\text { Twenty-five RCTs were } \\
\text { identified with } 1516 \\
\text { participants for this } \\
\text { review. }\end{array}$ & $\begin{array}{c}\text { Cao H/ } \\
2010\end{array}$ & fibromyalgia & $\begin{array}{l}\text { Wet cupping appears to be effective in the } \\
\text { treatment of fibromyalgia. }\end{array}$ & \\
\hline $\begin{array}{l}\text { The Efficacy of Wet-Cupping in the } \\
\text { Treatment of Tension and Migraine } \\
\text { Headache }\end{array}$ & $\begin{array}{l}70 \text { patients with } \\
\text { chronic tension or } \\
\text { migraine headache } \\
\text { were treated with } \\
\text { wet-cupping. }\end{array}$ & $\begin{array}{l}\text { Ahmadi A. } \\
2008\end{array}$ & $\begin{array}{c}\text { Tension and } \\
\text { Migraine Headache }\end{array}$ & $\begin{array}{l}\text { Concluded that wet-cupping leads to clinical } \\
\text { relevant benefits for primary care patients with } \\
\text { headache. }\end{array}$ & $\mathrm{p}<.005$ \\
\hline $\begin{array}{l}\text { Is cupping therapy effective in patients } \\
\text { with neck pain? }\end{array}$ & $\begin{array}{l}\text { Eighteen reviews } \\
\text { were selected }\end{array}$ & Kim S. & Neck pain & $\begin{array}{l}\text { Cupping was found to reduce neck pain in } \\
\text { patients compared with no intervention or } \\
\text { active control groups, or as an add-on } \\
\text { treatment. }\end{array}$ & $\mathrm{p}=.001$ \\
\hline $\begin{array}{l}\text { Cupping therapy for knee } \\
\text { osteoarthritis: a synthesis of evidence. } \\
\text { Complementary medicine research. }\end{array}$ & $\begin{array}{l}\text { A total of } 5 \\
\text { randomized controlled } \\
\text { trials met our inclusion } \\
\text { criteria. (involved } 535 \\
\text { participants.) }\end{array}$ & $\begin{array}{l}\text { Wang Y. } \\
2018\end{array}$ & Knee osteoarthritis & $\begin{array}{l}\text { There is weak evidence to support the } \\
\text { hypothesis that cupping therapy has beneficial } \\
\text { effects on reducing the pain intensity and } \\
\text { improving the physical function in patients with } \\
\text { knee osteoarthritis. }\end{array}$ & \\
\hline $\begin{array}{l}\text { Immunomodulatory effects of blood } \\
\text { letting cupping therapy in patients with } \\
\text { rheumatoid arthritis. }\end{array}$ & $\begin{array}{l}\text { Randomized } \\
\text { controlled trial }\end{array}$ & $\begin{array}{l}\text { Ahmed } \\
\text { SM./2005 }\end{array}$ & $\begin{array}{l}\text { Rheumatoid } \\
\text { arthritis }\end{array}$ & $\begin{array}{l}\text { In conclusion, BLC therapy combined with } \\
\text { conventional therapy may improve the clinical } \\
\text { condition of patients with rheumatoid arthritis. }\end{array}$ & $\mathrm{p}<.001$ \\
\hline $\begin{array}{l}\text { Effects of traditional cupping therapy } \\
\text { in patients with carpal tunnel } \\
\text { syndrome: a randomized controlled } \\
\text { trial. }\end{array}$ & $\begin{array}{l}\text { Randomized } \\
\text { controlled trial }\end{array}$ & $\begin{array}{l}\text { Michalsen } \\
\text { A./2009 }\end{array}$ & $\begin{array}{l}\text { Carpal tunnel } \\
\text { syndrome }\end{array}$ & $\begin{array}{l}\text { Cupping therapy may be effective in relieving } \\
\text { the pain and other symptoms related to carpal } \\
\text { tunnel syndrome }\end{array}$ & $\begin{array}{l}\mathrm{p}<.006, \\
\mathrm{p}<.007\end{array}$ \\
\hline $\begin{array}{l}\text { Al-hijamah (wet cupping therapy of } \\
\text { prophetic medicine) as a novel } \\
\text { alternative to surgery for carpal tunnel }\end{array}$ & Case reports & $\begin{array}{l}\text { Aboonq } \\
\text { MS./2019 }\end{array}$ & $\begin{array}{l}\text { Carpal tunnel } \\
\text { syndrome }\end{array}$ & $\begin{array}{l}\text { Immediately after Al-hijamah, a dramatic } \\
\text { decrease in pain, numbness and parathesia } \\
\text { occurred. Nerve conduction velocity and }\end{array}$ & \\
\hline
\end{tabular}




\begin{tabular}{lll}
\hline Name of the study $\quad$ Type of scientific study $\begin{array}{l}\text { Author of } \\
\text { study/year }\end{array}$ Subject of study Result $\quad$ value \\
\hline
\end{tabular}

electromyography carried out few days after Al-hijamah confirmed improved voluntary motor unit morphologies in both hands. The severe degree of bilateral carpal tunnel syndrome improved electrophysiologically to

syndrome. be moderate. Scheduled surgical intervention was cancelled. This did better than a German report treating carpal tunnel syndrome using traditional Chinese wet cupping therapy at the trapezius muscle without applying sucking cups at the carpal region.

Cupping in dermatology: a critical
review and update.
Cupping therapy: An analysis of the
effects of suction on skin and the
possible influence on human health.

Review $\begin{array}{cc}\text { Soliman Y. } \\ / 2018\end{array} \quad \begin{gathered}\text { Dermatological } \\ \text { condition }\end{gathered}$

Cupping has a promising role in helping manage dermatological conditions.

Besides the mechanical effect of cupping increasing the local blood flow and stretching Review Lowe DT. Dermatological underlying tissue, activation of the Heme $/ 2017 \quad$ condition Oxygenase-1 system could account for many of cupping therapy's claimed local and systemic health benefits.

\begin{tabular}{|c|c|c|c|c|c|}
\hline $\begin{array}{l}\text { Postherpetic neuralgia: practical } \\
\text { experiences return to traditional } \\
\text { Chinese medicine. }\end{array}$ & Review & $\begin{array}{l}\text { Avijgan } \\
\text { M./2017 }\end{array}$ & $\begin{array}{l}\text { Postherpetic } \\
\text { neuralgia: }\end{array}$ & $\begin{array}{l}\text { In traditional medicine early treatment of } \\
\text { herpes causes a better effect on PHN pain } \\
\text { control. }\end{array}$ & \\
\hline $\begin{array}{l}\text { Cupping for stroke rehabilitation: a } \\
\text { systematic review. }\end{array}$ & $\begin{array}{c}\text { Review } \\
\text { (3 randomized clinical } \\
\text { trials (RCTs) and } 2 \\
\text { uncontrolled } \\
\text { observational studies) }\end{array}$ & $\begin{array}{c}\text { Lee MS./ } \\
2017\end{array}$ & $\begin{array}{l}\text { Stroke } \\
\text { rehabilitation }\end{array}$ & $\begin{array}{l}\text { There are not enough trials to provide evidence } \\
\text { for the effectiveness of cupping for stroke } \\
\text { rehabilitation because most of the included } \\
\text { trials compared the effects with unproven } \\
\text { evidence and were not informative. }\end{array}$ & \\
\hline $\begin{array}{l}\text { A close look at an integrative treatment } \\
\text { package for Bell's palsy in Korea. }\end{array}$ & Review & $\begin{array}{l}\text { Lee SMK./ } \\
2017\end{array}$ & Bell's palsy & $\begin{array}{l}\text { Although rigorous research is warranted, with } \\
\text { limited treatment options, we highly suggest } \\
\text { that it is worth applying integrative medicine } \\
\text { to Bell's palsy patients. }\end{array}$ & \\
\hline $\begin{array}{l}\text { Effect of three-step acupuncture and } \\
\text { cupping therapy on cervicogenic } \\
\text { trigeminal neuralgia: A report of } \\
\text { clinical observation. }\end{array}$ & $\begin{array}{l}\text { Report of clinical } \\
\text { observation }\end{array}$ & $\begin{array}{l}\text { Jiang G. } \\
/ 2004\end{array}$ & $\begin{array}{c}\text { trigeminal } \\
\text { neuralgia }\end{array}$ & $\begin{array}{l}\text { Cupping therapy and acupuncture therapy can } \\
\text { also be effective in trigeminal neuralgia. }\end{array}$ & \\
\hline $\begin{array}{l}\text { Wet cupping therapy restores sympathovagal } \\
\text { imbalances in cardiac rhythm. }\end{array}$ & $\begin{array}{l}\text { Report of clinical } \\
\text { observation }\end{array}$ & $\begin{array}{l}\text { Arslan M. } \\
\text { /2014 }\end{array}$ & Cardiac rhythm. & $\begin{array}{l}\text { These results indicate for the first time in } \\
\text { humans that cupping might be cardioprotective. }\end{array}$ & \\
\hline $\begin{array}{l}\text { The effectiveness of dry-cupping in } \\
\text { preventing post-operative nausea and } \\
\text { vomiting by P6 acupoint stimulation: } \\
\text { A randomized controlled trial. }\end{array}$ & $\begin{array}{l}\text { Randomized } \\
\text { controlled trial }\end{array}$ & $\begin{array}{l}\text { Farhadi } \\
\text { K./2016 }\end{array}$ & $\begin{array}{l}\text { post-operative } \\
\text { nausea and } \\
\text { vomiting }\end{array}$ & $\begin{array}{l}\text { The experimental group who received dry cupping } \\
\text { had significantly lower levels of PONV severity } \\
\text { after surgery than the control group. The } \\
\text { differences in measure were maintained after } \\
\text { controlling for age and ASA in regression models. }\end{array}$ & $\begin{array}{c}\mathrm{p}<.001 \\
\mathrm{p}<.01\end{array}$ \\
\hline $\begin{array}{l}\text { A meta analysis on randomized } \\
\text { controlled trials of acupuncture } \\
\text { treatment of chronic fatigue syndrome. }\end{array}$ & Review. & $\begin{array}{l}\text { Wang JJ./ } \\
2009\end{array}$ & $\begin{array}{l}\text { Chronic fatigue } \\
\text { syndrome. }\end{array}$ & $\begin{array}{l}\text { traditional chinese medicine is effective for } \\
\mathrm{CFS} \text {, but still needs being confirmed by more } \\
\text { high-quality studies. }\end{array}$ & \\
\hline $\begin{array}{l}\text { Moving cupping at Hechelu combined } \\
\text { with rubbing method for depression of } \\
\text { diabetes mellitus. }\end{array}$ & $\begin{array}{l}\text { Randomized } \\
\text { controlled trial }\end{array}$ & $\begin{array}{c}\text { He L./ } \\
2016\end{array}$ & $\begin{array}{c}\text { Depression of } \\
\text { diabetes mellitus. }\end{array}$ & $\begin{array}{l}\text { The Hechelu theory-based TCM treatment has } \\
\text { better: efficacy for depression of diabetes } \\
\text { mellitus than fluoxetine hydrochloride capsule, } \\
\text { which has less adverse effects. }\end{array}$ & $\mathrm{p}<.05$ \\
\hline
\end{tabular}




\begin{tabular}{|c|c|c|c|c|c|}
\hline Name of the study & Type of scientific study & $\begin{array}{l}\text { Author of } \\
\text { study/year }\end{array}$ & Subject of study & Result & $\mathrm{p}$ value \\
\hline $\begin{array}{l}\text { The effects of wet cupping on serum } \\
\text { high-sensitivity C-reactive protein } \\
\text { and heat shock protein } 27 \text { antibody } \\
\text { titers in patients with metabolic } \\
\text { syndrome. }\end{array}$ & $\begin{array}{l}\text { Randomized } \\
\text { controlled trial }\end{array}$ & $\begin{array}{c}\text { Farahman } \\
\text { d SK./ } \\
2014\end{array}$ & $\begin{array}{l}\text { Metabolic } \\
\text { syndrome. }\end{array}$ & $\begin{array}{l}\text { Wet-cupping on the interscapular region has no } \\
\text { effect on serum hs-CRP and Hsp } 27 \text { patients } \\
\text { with metabolic syndrome. }\end{array}$ & $\mathrm{p}<.05$ \\
\hline $\begin{array}{l}\text { The effects of wet cupping on coronary } \\
\text { risk factors in patients with metabolic } \\
\text { syndrome: a randomized controlled } \\
\text { trial. }\end{array}$ & $\begin{array}{l}\text { Randomized } \\
\text { controlled trial }\end{array}$ & $\begin{array}{c}\text { Farahman } \\
\text { d SK./ } \\
2012\end{array}$ & $\begin{array}{l}\text { Metabolic } \\
\text { syndrome. }\end{array}$ & $\begin{array}{l}\text { Wet cupping does not have a significant effect } \\
\text { on anthropometric or biochemical indices } \\
\text { compared to the effect of dietary advice. }\end{array}$ & $\mathrm{p}<.05$ \\
\hline
\end{tabular}

The effect of wet cupping on serum lipid concentrations of clinically healthy young men: a randomized controlled trial.

Randomized Niasari
controlled trial M./2007

A substantial decrease in LDL cholesterol ( $\mathrm{p}$ $<.0001)$ and in the LDL/HDL ratio $(\mathrm{p}<.0001)$ was found in the treated group compared to the control. There were no significant changes in serum triglyceride between groups $(\mathrm{p}>.05) . \quad \mathrm{P}<.5$,

Serum lipid Although there were no statistically significant $\mathrm{p}<.001$ variations in total cholesterol and HDL cholesterol $(\mathrm{p}>.05)$, a $7 \%$ decrease in total cholesterol and 3\% increase in HDL cholesterol may be clinically important.

A few small studies suggested that wet cupping alone versus antihypertensive medication significantly reduced blood pressure and

Wet cupping for hypertension: a systematic review and meta-analysis.
Review

Lu S./ 2019
Hypertension
Traditional Chinese Medicine syndrome (hypertension-related symptoms). However based on current evidence, no firm conclusions can be drawn and no clinical recommendations made.

$\begin{array}{ccc}\text { M } & \text { The evidence is not significantly convincing } \\ \text { to suggest cupping is effective for treating }\end{array}$ M. $/ 2017$ cardiovasculer disorders. Acupuncture, cupping plus acupoint catgut embedding therapy can increase therapeutic effect on simple obesity of stomach and intestine excess-heat type, and it is a better method for treatment of this disease.

Comparison of therapeutic effects of acupuncture-cupping plus acupoint catgut embedding and electroacupuncture Review Shi Y./ Obesity on simple obesity of stomach and 2006 Al-hijamah may have better therapeutic Ameliorating role exerted by Al-Hijamah in autoimmune diseases: effect on serum autoantibodies and

Review Baghdadi Autoimmune diseases benefits than plasmapheresis. Al-hijamah may inflammatory mediators.

(1)

(n)
be promising in treating autoimmune diseases as a sole treatment or adjuvant treatment.

Al-hijamah may be superior to phlebotomy, and it needs to be researched further for educational evaluation in treating iron overload. Oral honey

Al-hijamah and oral honey for treating thalassemia, conditions of iron overload, and hyperferremia: toward improving the therapeutic outcomes.
Review
Thalassemia,

El Sayed conditions of iron

SM./ overload, and

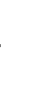

.




\begin{tabular}{|c|c|c|c|c|c|}
\hline Name of the study & Type of scientific study & $\begin{array}{l}\text { Author of } \\
\text { study/year }\end{array}$ & Subject of study & Result & $\mathrm{p}$ value \\
\hline $\begin{array}{l}\text { Percutaneous excretion of iron and } \\
\text { ferritin (through Al-hijamah) as a novel } \\
\text { treatment for iron overload in beta- } \\
\text { thalassemia major, hemochromatosis } \\
\text { and sideroblastic anemia. }\end{array}$ & Review & $\begin{array}{l}\text { El Sayed } \\
\text { SM./2014 }\end{array}$ & $\begin{array}{l}\text { Iron overload in beta- } \\
\text { thalassemia major, } \\
\text { hemochromatosis } \\
\text { and sideroblastic } \\
\text { anemia. }\end{array}$ & $\begin{array}{l}\text { Al-hijamah may be a promising adjuvant } \\
\text { treatment for iron overload in thalassemia, } \\
\text { hemochromatosis and sideroblastic anemia. }\end{array}$ & \\
\hline $\begin{array}{l}32 \text { cases of acute mastitis treated with } \\
\text { acupuncture, moxibustion and cupping. }\end{array}$ & Case report & $\begin{array}{c}\text { Zhaoping } \\
\text { L./1988 }\end{array}$ & Acute mastitis & $\begin{array}{l}\text { Acupuncture, moxibustion and cupping therapy } \\
\text { can be effective in acute mastitis. }\end{array}$ & \\
\hline $\begin{array}{l}\text { Bloodletting combined with medicinal } \\
\text { cupping and moxibustion for } 36 \text { cases of } \\
\text { insect bite dermatitis with lymphangitis. }\end{array}$ & Case report & $\begin{array}{c}\text { Zhao L./ } \\
2016\end{array}$ & Dermatitis & $\begin{array}{l}\text { Bloodletting with medical cupping and } \\
\text { moxibustion may be effective in dermitis with } \\
\text { lymphangitis caused by insect bites. }\end{array}$ & \\
\hline $\begin{array}{l}\text { Seventy-eight cases of humeral } \\
\text { epicondylitis treated by pricking and } \\
\text { cupping combined with moxibustion. }\end{array}$ & Case report & $\begin{array}{l}\text { Ning G-L./ } \\
2014\end{array}$ & $\begin{array}{l}\text { humeral } \\
\text { epicondylitis }\end{array}$ & $\begin{array}{l}\text { Humeral epicondylitis was treated with } \\
\text { needling and cupping together with plaster. }\end{array}$ & \\
\hline $\begin{array}{l}\text { Use of complementary and alternative } \\
\text { medicine at Norwegian and Danish } \\
\text { hospitals. }\end{array}$ & Survey & $\begin{array}{l}\text { Salomonsen } \\
\text { LJ./2011 }\end{array}$ & $\begin{array}{l}\text { Norwegian and } \\
\text { Danish hospitals }\end{array}$ & $\begin{array}{l}\text { The extent of complementary and alternative } \\
\text { medicine being offered has increased } \\
\text { substantially in Norway and Danish during the } \\
\text { first decade of the } 21 \text { (st) century. }\end{array}$ & \\
\hline $\begin{array}{l}\text { Prevalence of complementary and } \\
\text { alternative medicine usage in Vietnamese } \\
\text { American asthmatic children. }\end{array}$ & Survey & $\begin{array}{c}\text { Berg J// } \\
2016\end{array}$ & Vietnamese & $\begin{array}{l}\text { They found that CAM therapy is common in } \\
\text { Vietnamese asthmatic children }\end{array}$ & \\
\hline $\begin{array}{l}\text { Complementary and alternative medicines: } \\
\text { usage and its determinant factors } \\
\text { among outpatients in Southeast of Iran. }\end{array}$ & Survey & $\begin{array}{l}\text { Ghaedi F./ } \\
2017\end{array}$ & Iran & $\begin{array}{l}\text { A comprehensive context-based understanding of } \\
\text { the complementary and alternative medicine usage } \\
\text { and determinant factors may assist health care } \\
\text { providers to design suitable interventions to } \\
\text { educate and evaluate the outcomes of using } \\
\text { complementary and alternative medicine. }\end{array}$ & \\
\hline $\begin{array}{l}\text { Evaluation of wet cupping therapy: } \\
\text { systematic review of randomized } \\
\text { clinical trials. }\end{array}$ & $\begin{array}{l}\text { Meta analysis } \\
\text { (Fourteen randomized } \\
\text { controlled trials) }\end{array}$ & $\begin{array}{l}\text { Al Bedah } \\
\text { AMN./ } \\
2016\end{array}$ & Meta analysis & $\begin{array}{l}\text { There is a promising evidence in favor of the } \\
\text { use of wet cupping for musculoskeletal pain, } \\
\text { specifically nonspecific low back pain, neck } \\
\text { pain, CTS, and brachialgia. }\end{array}$ & \\
\hline $\begin{array}{l}\text { Skin scraping, cupping, and moxibustion } \\
\text { that may mimic physical abuse. }\end{array}$ & Review & $\begin{array}{l}\text { Look KM. } \\
\text { /1997 }\end{array}$ & Physical abuse. & $\begin{array}{l}\text { there are some cultural practices of Oriental medicine } \\
\text { that may mimic physical and/or child abuse. }\end{array}$ & \\
\hline $\begin{array}{l}\text { Developing and validating a sham } \\
\text { cupping device. }\end{array}$ & Others & $\begin{array}{l}\text { Lee MS./ } \\
2010\end{array}$ & $\begin{array}{l}\text { Sham cupping } \\
\text { device. }\end{array}$ & $\begin{array}{l}\text { We developed a new sham cupping device that } \\
\text { seems to provide a credible control for real } \\
\text { cupping therapy by producing little or no } \\
\text { negative pressure. }\end{array}$ & \\
\hline $\begin{array}{l}\text { Numerical analysis of the change in } \\
\text { skin color due to ecchymosis and } \\
\text { petechiae generated by cupping: a pilot } \\
\text { study. }\end{array}$ & $\begin{array}{l}\text { In the study performed on } \\
30 \text { men, skin discoloration } \\
\text { was examined before } \\
\text { and } 72 \text { hours after } \\
\text { cupping therapy. }\end{array}$ & $\begin{array}{l}\text { Kim S-B./ } \\
2014\end{array}$ & $\begin{array}{l}\text { Change in skin } \\
\text { color. }\end{array}$ & $\begin{array}{l}\text { Cupping leads to changes in skin such as } \\
\text { pigmentation and blood purification mechanisms } \\
\text { in the body. }\end{array}$ & \\
\hline $\begin{array}{l}\text { Bloodletting-induced cardiomyopathy: } \\
\text { reversible cardiac hypertrophy in } \\
\text { severe chronic anaemia from long-term } \\
\text { bloodletting with cupping. }\end{array}$ & Side effect & $\begin{array}{l}\text { Sohn I-S./ } \\
2008\end{array}$ & $\begin{array}{l}\text { Reversible cardiac } \\
\text { hypertrophy }\end{array}$ & $\begin{array}{l}\text { Cardiac hypertrophy developed in a patient } \\
\text { with severe iron deficiency anemia due to } \\
\text { prolonged blood draw with cupping therapy. }\end{array}$ & \\
\hline $\begin{array}{l}\text { Hijama therapy (wet cupping)-its } \\
\text { potential use to complement British } \\
\text { healthcare in practice, understanding, } \\
\text { evidence and regulation. }\end{array}$ & Survey & $\begin{array}{l}\text { Sajid MI./ } \\
2016\end{array}$ & England & $\begin{array}{l}\text { Hijama (wet cupping) therapy might also be } \\
\text { considered for use too in a similar way by } \\
\text { medical professionals and regulatory bodies as } \\
\text { an alternative non-pharmacological treatment } \\
\text { or potentially a complementary therapy to } \\
\text { benefit patients. }\end{array}$ & \\
\hline
\end{tabular}


diseases such as osteoarthritis (4 pieces), rheumatoid arthritis (1 piece), ankylosing spondylitis (2 pieces), gout, carpal tunnel syndrome (2 pieces), cervical spondylosis and limb spasticity, cupping therapy was found to be effective in bone / musculature diseases. Moreover, in the reviews carried out on this subject, it has been concluded that cupping therapy is effective in musculoskeletal diseases (Table 1) [11-14].

In a RCS, dry cupping was found to be effective in the treatment of osteoarthritis.

In 16 RCS studies on skin diseases such as neurodermatitis, herpes simplex, chronic urticaria, acne vulgaris, and acute eczema, results were obtained regarding that cupping therapy was effective (Table 1) [15]. Cupping therapies were applied on and around the skin lesion in these studies.

When we look at the effectiveness of cupping therapy in nervous system diseases; there are results showing that it is effective in 15 RCSs performed in diseases such as facial paralysis, peroneal nerve palsy, cerebral palsy, brachial paresthesia, postherpetic neuralgia, migraine and trigeminal neuralgia. All the studies performed were performed on wet mug, and also the mug applications in these studies were applied along the nerve tract where the lesion was located and around the nerve (Table 1) $[8,17,20]$.

In an RCS performed on hypertension, cupping therapy was effective in the first 4 weeks but the following 8th week, it was concluded that its effectiveness decreased. In a review carried out on hypertension, it was concluded that cupping therapy may be effective, but more research is needed. In another review, it was concluded that there is not enough evidence to show that cupping therapy is effective in the treatment of hypertension (Table 1) [28].

Apart from these, there are studies and case reports that cupping therapy is effective in the treatment of cardiovascular diseases, obesity, hyperlipidemia, hypertension, autoimmune diseases, epistaxis, superficial thrombophlebitis therapy, mastitis, insect sting with lymphangitis, epicondylitis treatment, gluteal nerve junction syndrome and epistaxis, and with further RCSs to be performed, cupping therapy will be able to take its place in the treatment protocols for these and similar diseases (Table 1) [4,27-31,34,36-38].

\section{Conclusion}

Despite being a very common treatment method today, the lack of basic physiological and clinical data causes this therapy, which has made itself accepted among the public to not see the value it deserves in western medicine. We are of the opinion that in recent years, with increasing RCSs on cupping therapy carried out particularly in the west, cupping therapy will be started to be applied by physicians all over the world and gain the respect it deserves.

\section{References}

[1] Cui S, Cui J. [Progress of researches on the mechanism of cupping therapy]. Zhen Ci Yan Jiu. 2012;37(6):506-10.

[2] Furhad S, Bokhari AA. Cupping Therapy. In: StatPearls. Treasure Island(FL). StatPearls. 2021.

[3] Mehta P, Dhapte V. Cupping therapy: A prudent remedy for a plethora of medical ailments. J Tradit Complement Med. 2015;10;5(3):127-34.

[4] Al-Bedah AMN, Elsubai IS, Qureshi NA, Aboushanab TS, Ali GIM, El-Olemy AT, Khalil AAH, Khalil MKM, Alqaed MS. The medical perspective of cupping therapy: Effects and mechanisms of action. J Tradit Complement Med. 2018;30;9(2):90-7.

[5] Murray D, Clarkson C. Effects of moving cupping therapy on hip and knee range of movement and knee flexion power: a preliminary investigation. J Man Manip Ther. 2019;27(5):287-294.

[6] Cao H, Zhu C, Liu J. Wet cupping therapy for treatment of herpes zoster: a systematic review of randomized controlled trials. Altern Ther Health Med. 2010;16(6): 48-54. 
[7] Cao H, Liu J, Lewith GT. Traditional Chinese Medicine for treatment of fibromyalgia: a systematic review of randomized controlled trials. J Altern Complement Med. 2010;16(4):397-409.

[8] Ahmadi A, Schwebel DC, Rezaei M. The efficacy of wet-cupping in the treatment of tension and migraine headache. Am J Chin Med. 2008;36(1):37-44.

[9] Kim S, Lee SH, Kim MR, Kim EJ, Hwang DS, Lee J, Shin JS, Ha IH, Lee YJ. Is cupping therapy effective in patients with neck pain? A systematic review and meta-analysis. BMJ Open. 2018;8(11):e021070.

[10] Parkitny L, McAuley JH, Di Pietro F, Stanton TR, O'Connell NE, Marinus J, van Hilten JJ, Moseley GL. Inflammation in complex regional pain syndrome: a systematic review and meta-analysis. Neurology. 2013 ;80(1):106-17.

[11] Wang YL, An CM, Song S, Lei FL, Wang Y. Cupping Therapy for Knee Osteoarthritis: A Synthesis of Evidence. Complement Med Res. 2018;25(4):249-55.

[12] Ahmed SM, Madbouly NH, Maklad SS, Abu-Shady EA. Immunomodulatory effects of blood letting cupping therapy in patients with rheumatoid arthritis. Egypt J Immunol. 2005;12(2):39-51.

[13] Michalsen A, Bock S, Lüdtke R, Rampp T, Baecker $\mathrm{M}$, Bachmann J, et al. Effects of traditional cupping therapy in patients with carpal tunnel syndrome: a randomized controlled trial. The journal of pain. 2009;10(6):601-8.

[14] Aboonq MS. Al-hijamah (wet cupping therapy of prophetic medicine) as a novel alternative to surgery for carpal tunnel syndrome. Neurosciences (Riyadh). 2019;24(2): $137-42$.

[15] Soliman Y, Hamed N, Khachemoune A. Cupping in dermatology: a critical review and update. Acta Dermatovenerol Alp Pannonica Adriat. 2018;27(2): 103-7.

[16] Lowe DT. Cupping therapy: An analysis of the effects of suction on skin and the possible influence on human health. Complement Ther Clin Pract. 2017 Nov;29:162-8.

[17] Avijgan M, Hajzargarbashi ST, Kamran A, Avijgan M. Postherpetic Neuralgia: Practical Experiences Return to Traditional Chinese Medicine. J Acupunct Meridian Stud. 2017;10(3):157-164.

[18] Lee MS, Choi TY, Shin BC, Han CH, Ernst E. Cupping for stroke rehabilitation: a systematic review. J Neurol Sci. 2010;294(1-2):70-3.

[19] Lee SM, Lee S, Park JH, Park JJ, Lee S. A close look at an integrative treatment package for Bell's palsy in Korea. Complement Ther Clin Pract. 2017;26:76-83.

[20] Jiang GL, Xia XY, Li JJ. [Effect of three-step acupuncture and cupping therapy on cervicogenic trigeminal neuralgia: a report of clinical observation]. Zhong Xi Yi Jie He Xue Bao. 2004;2(2):139-40.

[21] Arslan M, Yeşilçam N, Aydin D, Yüksel R, Dane S. Wet cupping therapy restores sympathovagal imbalances in cardiac rhythm. J Altern Complement Med. 2014; 20(4):318-21.

[22] Farhadi K, Choubsaz M, Setayeshi K, Kameli M, Bazargan-Hejazi S, Zadie ZH, Ahmadi A. The effectiveness of dry-cupping in preventing post-operative nausea and vomiting by P6 acupoint stimulation: A randomized controlled trial. Medicine (Baltimore). 2016; 95(38):e4770.

[23] Wang JJ, Song YJ, Wu ZC, Chu XO, Wang XH, Wang XJ, Wei LN, Wang QM. [A meta analysis on randomized controlled trials of acupuncture treatment of chronic fatigue syndrome]. Zhen Ci Yan Jiu. 2009;34(6):421-8.

[24] He L, Du P, Shen Z, Wang X. [Moving cupping at Hechelu combined with rubbing method for depression of diabetes mellitus]. Zhongguo Zhen Jiu. 2016;36(3): 245-9.

[25] Farahmand SK, Gang LZ, Saghebi SA, Mohammadi M, Mohammadi S, Mohammadi G, Ferns GA, Ghanbarzadeh M, Razmgah GG, Ramazani Z, Ghayour-Mobarhan M, Esmaily H, Bahrami Taghanaki H, Azizi H. The effects of wet cupping on serum high-sensitivity C-reactive 
protein and heat shock protein 27 antibody titers in patients with metabolic syndrome. Complement Ther Med. 2014; 22(4):640-4.

[26] Farahmand SK, Gang LZ, Saghebi SA, Mohammadi M, Mohammadi S, Mohammadi G, Ferns GA, Zadeh MG, Razmgah GG, Ramazani Z, Ghayour-Mobarhan M, Azizi $\mathrm{H}$. The effects of wet cupping on coronary risk factors in patients with metabolic syndrome: a randomized controlled trial. Am J Chin Med. 2012;40(2):269-77.

[27] Niasari M, Kosari F, Ahmadi A. The effect of wet cupping on serum lipid concentrations of clinically healthy young men: a randomized controlled trial. J Altern Complement Med. 2007;13(1):79-82.

[28] Lu S, Du S, Fish A, Tang C, Lou Q, Zhang X. Wet cupping for hypertension: a systematic review and meta-analysis. Clin Exp Hypertens. 2019;41(5):474-80.

[29] Zarshenas MM, Zargaran A, Blaschke M. Convenient, Traditional and Alternative Therapies for Cardiovascular Disorders. Curr Pharm Des. 2017;23(7):1112-8.

[30] Shi Y, Zhang LS, Zhao C, He CQ. [Comparison of therapeutic effects of acupuncture-cupping plus acupoint catgut embedding and electroacupuncture on simple obesity of stomach and intestine excess-heat type]. Zhongguo Zhen Jiu. 2006;26(8):547-50.

[31] Baghdadi H, Abdel-Aziz N, Ahmed NS, Mahmoud HS, Barghash A, Nasrat A, Nabo MM, El Sayed SM. Ameliorating Role Exerted by Al-Hijamah in Autoimmune Diseases: Effect on Serum Autoantibodies and Inflammatory Mediators. Int J Health Sci (Qassim). 2015;9(2):207-32.

[32] El Sayed SM, Baghdadi H, Abou-Taleb A, Mahmoud HS, Maria RA, Ahmed NS, Helmy Nabo MM. Al-hijamah and oral honey for treating thalassemia, conditions of iron overload, and hyperferremia: toward improving the therapeutic outcomes. J Blood Med. 2014;5:219-37.

[33] Wang JX, Yang Y, Song Y, Ma LX. Positive Effect of Acupuncture and Cupping in Infertility Treatment. Med Acupunct. 2018;30(2):96-9.
[34] El Sayed SM, Abou-Taleb A, Mahmoud HS, Baghdadi H, Maria RA, Ahmed NS, Nabo MM. Percutaneous excretion of iron and ferritin (through Al-hijamah) as a novel treatment for iron overload in beta-thalassemia major, hemochromatosis and sideroblastic anemia. Med Hypotheses. 2014;83(2):238-46.

[35] Wang T. [Superficial thrombotic phlebitis treated by blood-letting and cupping therapy]. Zhongguo Zhen Jiu. 2011;31(1):22

[36] Liang ZP. 32 cases of acute mastitis treated with acupuncture, moxibustion and cupping. J Tradit Chin Med. 1988;8(1):15-8.

[37] Zhao L, Zhen Wen, Huang X. [Bloodletting combined with medicinal cupping and moxibustion for 36 cases of insect bite dermatitis with lymphangitis]. Zhongguo Zhen Jiu. 2016;36(1):57-8.

[38] Ning GL, He SY, Liu XL. [Seventy-eight cases of humeral epicondylitis treated by pricking and cupping combined with moxibustion]. Zhongguo Zhen Jiu. 2014;34(1):20.

[39] Salomonsen LJ, Skovgaard L, la Cour S, Nyborg L, Launse L, Fønnebø V. Use of complementary and alternative medicine at Norwegian and Danish hospitals. BMC Complement Altern Med. 2011;11:4.

[40] Haller JS Jr. The glass leech. Wet and dry cupping practices in the nineteenth century. N Y State J Med. 1973; 73(4):583-92.

[41] Berg J, Morphew T, Tran J, Kilgore D, Galant SP. Prevalence of Complementary and Alternative Medicine Usage in Vietnamese American Asthmatic Children. Clin Pediatr (Phila). 2016;55(2):157-64.

[42] Cui J, Zhang GQ. A survey for thirty years' clinical application of cupping. J Tradit Chin Med. 1989;9(2): 151-4.

[43] Ghaedi F, Dehghan M, Salari M, Sheikhrabori A. Complementary and Alternative Medicines: Usage and Its Determinant Factors Among Outpatients in Southeast of Iran. J Evid Based Complementary Altern Med. 2017; 22(2):210-5. 
[44] Stoeckle DB, Carter RD. Cupping in New York State--1978; historic review. N Y State J Med. 1980; 80(1):117-20.

[45] Al Bedah AM, Khalil MK, Posadzki P, Sohaibani I, Aboushanab TS, AlQaed M, Ali GI. Evaluation of Wet Cupping Therapy: Systematic Review of Randomized Clinical Trials. J Altern Complement Med. 2016; 22(10):768-77.

[46] Look KM, Look RM. Skin scraping, cupping, and moxibustion that may mimic physical abuse. J Forensic Sci. 1997;42(1):103-5.

[47] Lee MS, Kim JI, Kong JC, Lee DH, Shin BC. Developing and validating a sham cupping device. Acupunct Med. 2010;28(4):200-4.
[48] Kim SB, Lee YH. Numerical analysis of the change in skin color due to ecchymosis and petechiae generated by cupping: a pilot study. J Acupunct Meridian Stud. 2014;7(6):306-17.

[49] Sohn IS, Jin ES, Cho JM, Kim CJ, Bae JH, Moon JY, Lee SH, Kim MJ. Bloodletting-induced cardiomyopathy: reversible cardiac hypertrophy in severe chronic anaemia from long-term bloodletting with cupping. Eur J Echocardiogr. 2008;9(5):585-6.

[50] Sajid MI. Hijama therapy (wet cupping) - its potential use to complement British healthcare in practice, understanding, evidence and regulation. Complement Ther Clin Pract. 2016;23:9-13. 